\title{
Implementation of Social Function in Land Acquisition
}

\author{
I Ketut Kasta Arya Wijaya, I Wayan Arthanaya \\ Faculty of Law \\ Universitas Warmadewa \\ Denpasar-Bali, Indonesia \\ kastaaryawijaya@gmail.com
}

\begin{abstract}
This paper describes the implementation of social function in the acquisition of land as enacted in article 6 of Basic Agrarian Law (UUPA). This research belongs to the type of normative legal research. To examine the problems in this research, we use statutory approach, conceptual approach and case approach. The results show that the principle of social function is often identified with the public interest and this is often misunderstood even in the twisted purpose of the meaning of public interest and social functions and then for the ruler or state organizers in implementing social functions in land acquisition should stick to the philosophical basis of the social principle so that it is in favor of the community as a whole to provide benefits and realize a just and prosperous society. The government's efforts to provide a sense of justice in relation to the acquisition of land for the development of the public interest in which individual land is used as an object of public interest, the government must concern the rights that belong to the landowners.
\end{abstract}

\section{Keywords - social function; land acquisition; public interest}

\section{INTRODUCTION}

The issue of land acquisition for public interest is of concern to the government, this can be seen from the frequent legislation that keeps changing in the implementation order. Land issues are a matter of the most basic rights of the people. Land in addition to having economic value also function socially, therefore the private interest on the land is sacrificed for the public interest. This is done with the disposal of land rights by obtaining compensation that is not in the form of money alone but also in the form of land or other facilities [1]. Basically, philosophically the land has not originally been given to individuals. So it is not true that one who sells the land is selling his property, which is true he only sells the services of maintaining and maintaining the land for as long as it is mastered. This is true when examined more deeply that the land in addition to having economic value, also has a social value that means the right to land is not absolute. However, the state must guarantee and respect the rights granted to the land to its citizens guaranteed by law [2]. The problem of land acquisition is very vulnerable in handling it, because in it concerning the livelihood of the people, when viewed from the government's need for land for development purposes, it is understood that the available state land is very limited. Therefore the only way that can be taken is to free land owned by the community, whether it has been controlled by rights under customary law or other rights under the BAL.

The process of land acquisition will never be separated with the existence of compensation issues, it is necessary to conduct prior research on all information and data submitted in the assessment of compensation. So if an agreement has been reached on the form and size of the compensation, then a compensation payment will be made and then proceed with the release or assignment of the rights to the land concerned. For that researchers will examine the link between social functions, protection of human rights and the principle of justice in the implementation of land acquisition for development for the public interest. Buiding on the above elaboration, the questions raised to be answered in this study are: How does the implementation of the social function principle in land acquisition arrangements for development for the public interest be linked to the protection of human rights to property rights over transferred land?; and What is the government's efforts to provide a sense of justice for the release of land ownership rights in land acquisition for development for the public interest?

\section{METHOD}

This research belongs to the type of normative legal research. To examine the problems in this research, the approach used is: Statutory approach, conceptual approach and case approach. Sources of legal material is from the primary law and secondary law; the techniques used in the collection of legal materials that is by way of inventory, categorization with books and legislation related to the issues discussed, the analysis is descriptive analytical.

\section{RESUlT AND DISCUSSION}

\section{A. Implementation of Social Functions}

The interests of society and the interests of individuals must balance each other until the achievement of the ultimate goal, namely prosperity, justice, and happiness for the people as a whole [2]. The social function of the land rights is in line with the ground norm of Indonesia which aspires to the general welfare and social justice which is then poured into Article 33 of the 1945 Constitution concerning "the greatest prosperity of the people" and it can be interpreted that the social function of 
the property of primary, the property should not be allowed to harm the public interest. It is clear that between the concept of individuality and collectivity to the land must be equilibrium or single-billed. Thus the single- two is that every individual has a social function in accordance with Pancasila wherein that individual in addition to attaching individual interests also closer to social interests, for example, property rights may be uprooted in social interests.

The social function has a close relationship with the common good as defined in article 18 of the BAL (Basic Agrarian Law). In article 18 it states that, "For the public interest, including the interests of the nation and the state and common interests for the people, the rights to land may be revoked by compensating suitably in the manner prescribed in the Law" [3]. The principle of social function is still relevant implemented in the current context relating to the acquisition of land, but in its implementation is less favorable to lower society or weak economic groups who want to get justice in the field of land. Relation to policy is closely related to legal politics in the area of ariqah, the principle of social function is often identified with the public interest and this is often misunderstood even in the twisted purpose of the meaning of public interest and social functions in the government of the new order for example that the public interest is often used the ultimate weapon in obtaining land-owned by the community under the pretext that the development is done for the benefit of the people, whereas often the development undertaken is to benefit certain groups in order to benefit from business activities undertaken.

\section{B. Government efforts to provide a sense of Justice in the Implementation of Land acquisition.}

In his book A Theory of Justice Jhon Rawls [4] argues that "Justice is the main virtue in social institutions, as is the truth in the system of thought, and as the main virtue of mankind, righteousness and justice cannot be inviolable". The government's efforts to provide a sense of justice in relation to the acquisition of land for the development of the public interest in which individual land is used as an object of public interest, the government must still pay attention to the rights that belong to the landowners such as to obtain compensation in accordance with the needs of life at that time, place of substitute land used for public interest, and protection of social culture of people affected by land acquisition object.

\section{CONCLUSION}

Social Principles cannot be changed, the principle of social function remains relevant implemented in the current context relating to the acquisition of land, but in its implementation is not in favor of the lower society or the weak economic groups who want to get justice in the field of land. The government's efforts to provide a sense of justice in relation to the acquisition of land for the development of the public interest in which individual land is used as an object of public interest, the government must still pay attention to the rights that belong to the landowners such as to obtain compensation in accordance with the needs of life at that time, place of substitute land used for public interest, and protection of social culture of people affected by land acquisition object.

\section{ACKNOWLEDGEMENT}

The author would like to thank all the parties who have helped and contributed in the writing of this article, both those who contribute in the form of funding and critical ideas. Hopefully this paper can be useful theoretically and practically for the addition and development of knowledge, especially in the field of legal science.

\section{REFERENCES}

[1] A. Sutedi, Implementasi Prinsip Kepentingan Umum Dalam Pengadaan Tanah Untuk Pembangunan, Ed. 1, Cet. 2 Sinar Grafika, Jakarta. 2008.

[2] A. Saleng, Hukum Pertambangan. Penerbit UII Press. Yogyakarta. 2004.

[3] S. Gautama, Tafsiran Undang-Undang Pokok Agraria, Citra Aditya Bakti, Bandung. 1990.

[4] J. Rawls, A Theory of Justice: Teori Keadilan, Penerbit Pustaka Pelajar Jogyakarta. 2006. 